whether the duodenum is or is not short-circulted out of the alimentary cansl. The cause must be common to both obstructed and non-obstrusted cases, and is probably to be found in the regurgitation of alkaline bile and pancreatic juice into the stomach and in the consequent reduction of gastric acidity, together with the inhibition of the rennin.

4. That in cases of recurrent intractable duodenal or gastric ulceration, an operation is indicated whish will ensure the complete loss of the acld reaction of the stomach, while the benefit at present conferred in ulceration by gastro.enterostomy is due to the partial loss of that reaction. That such an operation would consist in closing the proximal $\epsilon$ d of the bowel and implanting the distal directly into the stomach. That where gastroenterostomy is rerformed the opening should be near the cardiac end of the stomach, and that the anastomosis should be simple, not Y.shaped, nor with enteroenterostomy.

5. That the complete digestion of fats on a mixed diet is due to the specific stimulating eff $s$ ct on the pancreas of a hormone produced by the fats themselves.

6. A case of malignant pyloric obstraction, aiter partial gastrectomy and posterior gastro-jejunostomy, showed complete power of dealing with fats.

Finally, I take the opportunity of pleading the laborious nature of the experiments carried out as an excuse for their small number, and of thanking the physicians and surgeons under whose care the patients were at Guy's Hospital, and Mr. Swan at the Cancer Hospital, for their kindness in so readily granting facilities for work which can have no claim to be conside red of the hightst practical importance.

Note.

In an address delivered at the annual meeting $n$ f the American Medical Asrociation, at Atlantic City, U.S A. and published in the Lanoet for September 21st, 1907, Mr. H. J. Paterson states that he has found little diminution in the power of digesting fat in 4 pattents upon whom he had performed gastro-jejunostomy, and who were placed upon a milk diet. Details as to the method adopted and the amount of milk given are wanting. The lat absorption, taking the average of 4 cases, is stated to have been only 1.17 below the normal. The present eng]yses were completed before the publication of this paper.

3 Work of the Digestive Glandy Pawnes.

Dlandy. Pawlow, English edition, 1902, p. 164 Croonian Lecture on The chemical Regulation of the Secretory Process, by W. M. Bayliss and 6. H. Starling, Proc Ro J. Soc vol. 1xxiii,

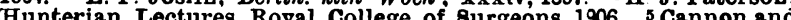
Blake vol xivi, Uctober, $190 \%$, p.519, 7 Puwlow, loc. cit., p. 163 , 8 Katzen stein, Deut. med. Woch, xxxili, 1907 '9 Pawlow, Joc. cit, p. 145 20 Denechau, Les suites médicales eloignées de la g istro-entérostomie Faculte de Médecine de Paris, 1907. 11 Zeitschrift fur Chir, 1xi, p. 337 12 Mayo Robion and Moynihan, Diseases of Scomach, p. 238. "12 Loc. cit 14 Annals of surgery, vol xlvi, $p .556 .15$ loc. cit. 16 Loc. cit. 37 Pawlow, loc cit $\dot{p} 121.18$ Pawlow, loc. cit. p. 122. 19 Starling
Recent Advances in the Physiology of Digestion, p. 92 .

\section{ETHER ANAESTHESIA BY THE OPEN METHOD.}

By H BELL 1MY GARDNER, M.R.C S, L R.C.P LOND LATE INSTRUCTOR IN AXAESTHETICS AT CHARISG CROSS HOSPITAL.

Sinc the sear 1876 when Mr. J. L. Clover Invented his portable gas and ether apparatus, it has until recently been the custom in England to administer the vapou ether as a general anaesthetlc br means of a closed indis rubber bag. Tnis method produces a very rapid insensibllity; the total amount of ether evaporated averages only $6 \mathrm{fl} . \mathrm{oz}$. an hour, and little vavour escapes into the surrounding atmosphere. Its disadvantazes are that the partial deprivation of air and rebreathing of explred products trom the bag tend to produce :

1. Daskiness of the countenance and oczing of venous blccd from the cat surfaces of the op?ration wound

2. Considerable secretion of mucus from the membranes of the air passages.

3. L3boared breathirg, with strong movement of the abdominal walls.

4. After-sickness in 75 per cent. of the oases.

These factors render the smooth conduct of ether anaesthesia with a bag inhaler more difficult than that of chlorolorm, with the resu!t that many practitloners do not attempt its use in private practlce, and that chloroform is also frequently resorted to by specialists when complete tran quillity is desired.

The open method of administering ether bas been used In America for geveral years, and the procedure which I now adopt, after a serles of careful trials and experiments with various materiale, consists in pouring ether upon a wire.framed mask covered with ten lasers of white sbsjrbent ganze such as is used for eurgical dressings. The mask, which may be of the Schlmmelbusch pattern, or constructed according to the anthor's epecial design shown in Fig. 1, is allowed to rest lightly upon a freshly-made gauze fase-pad consisting of several lajers of the came gauze made into a roll 14 in. long and 1 In. thick. The free ends of the roll are crossed and tied

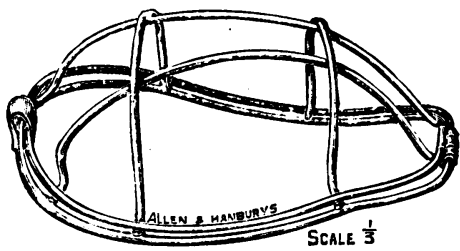

Fig. 1. together with a short plece of ganze or tape, 'as shown in Fig. 2, before the mask is applied. An 8.cz. medicine bottle, fitted with the double-tubed stopper illustrated in Fig. 3, is well adapted for the supply of ether, which can be poured from the end of either tube at a rate controlled by the finger held upon the other. To diminish the supply still farther the bottle may be held comewhst mpon its side, when a small stream of separate drops falls from the tube orifice. A larger stock of ether muet aleo be at hand, as in some cases from 12 to $16 \mathrm{oz}$.

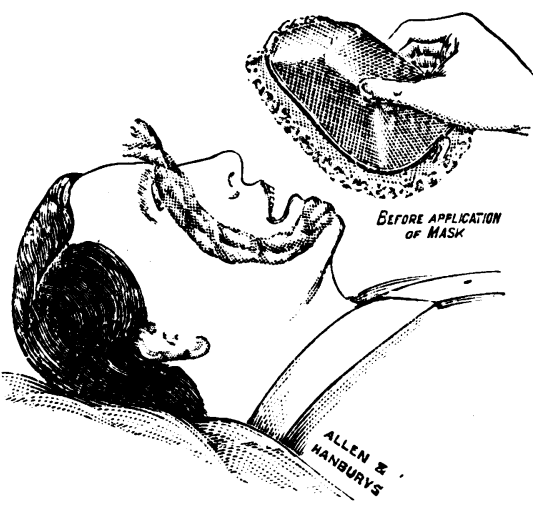

Fig. 2. may berequired or a long operaation.

THE ADMINISTRATION. The patient being in the supine position is first tcld to close the eyes, and the gauze face-pad is then $1008 \mathrm{ely}$ laid upon the face lorming an oval, which covers the closed eyelids and encircles the mouth and nose. The dry ether mask is then superimposed, and the patient is told to breathe regularly and slowly in and out through the mouth. A few drops of ether aro then allowed to fall upon the lower portion of the mask opposite to the mouth; and whilst verbally encouraging the patient to con. tinne this form of breathing, the drops of ether are steadily continued so as to keep the lower half of the ganze molat to the touch but not wet enongh to overflow. It is a good plan to keep talking steadily to the patlent, instructing him how to breathe and descrlbing the sensations he will experfeace until he drops off to sleep, so that the sound of the volce may gaide and control him while he remains conscious.

The taste of ether when presented in this manner is rot objected to by the majority cf patlents, because it is too weak to be pung $\lrcorner n t$. There is hardly any exsitement or atruggling except in alcohollc subjecte, for whom it should

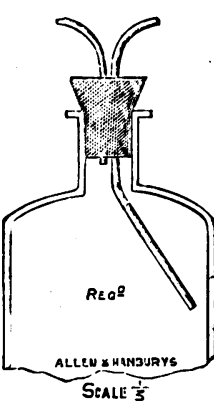

Fig. 3 . not be used. The only movement which may usually be antlclpated is a tendency 10 slowly raise the head and sit ap, which is often wituessed also curing the induction with $C_{1} E_{2}$ mixtune in adults. This need not be restrained, as it only lasts for 8 minute or 80 and if. the ether be steadily continued the patient will slowly sink back upon the pllows in the third stage of anaesthesia. The time taken to induce this condition is, on the average, between six and seven minutes. As a rale, whin slight stertor 
begins to arlise the anaesthetist's troubles are over, bat movement of the patient by commencing to wheel the conch along or to prepare the abdomen for operation at this moment is apt to Induce vomiting, so that the ether should be continued a little longer before doing elther.

Type of ANa Esthesia.

The remarkable difference in the type of anaesthesia when compared with that of the enclosed bag method is now apparent. The amount of mucus secreted in the mouth and fauces, trachea, and bronchl, is generally much less. There seems to be no tendency to coughing, retch. Ing, or laboured breathing; the depth of resplration is decidedly less in degree, and sudden changes in its type are rare. The colour of the face is pink, unless surgical shock or haemorrhage take place. The pulse-rate 1s, as a rule, about 80 to the minute, and its volume full, whilst the blood pressure is well maintained.

There is no oozing of venous blood from the operation wound nor congestion of the caplllary vessels. The musculature becomes completely relaxed, and reflex laryngeal spasm and disturbances of resplration caused by surgical stimuli are less marked than under any other anaes thetic. Abdominal movement is not heaving in character.

AFTER. RFFECTS.

My experience is that after-sickness and other bad effects, such as headache and taste of ether, are remarkably reduced; the patient being frequently quite undis turbed by any such seneatlons. This is corroborated by Drs. Weland and Osgood of Boston, Masse, who, writjng on gauze ether, ${ }^{1}$ state that the occurrence of post-ansesthetic vomiting is reduced to $32 \frac{1}{2}$ per cent., and translent acetonurla to 26 per cent. of the cases. Profuse perspiration occurs in many patients both during and after operation, and therefore, besides blanket clothing, the temperature of the operating room and bedroom should be main tained above $60^{\circ} \mathrm{F}$. I have found by experiment that the temperature of the air within the mask does not sink below $70^{\circ} \mathrm{F}$.

A.few details may now be given from the experience of Mis 3 Allce Magaw, anaesthetist to Dr. W. J. Mayo at St. Marg's Hospital, Rochester, Minn., which are recounted by. her In "A Revlew of over 14,000 surgical Anaesthesias ": 2

A much deeper narcosis is required to start an operstion or to make the inclsion than later on when the operstion is In progress.

Never bid a patient to "breathe deep" for in so doing a feeling of suffocation is sure to follow and the patient is also

apt to struggle.

Daring the oparation, as soon as the patient begins to 'get ontrol of the jaw, more complete narcosis is required.

Formerly operations for exophthalmio goître were : looked upon with a great deal of dread on account of the anaesthetic We have found these cases, when properly managed and the ether given by the drop method, were as good subjects as any other class of cases of the same gravity.

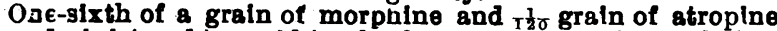
are administered to avold tracheal mucus thirty minates before operation.

The mask and gauze can be boiled, and the latter used again for further cases if desired. Instead of a gauze facepad I experimented with a rubber rim to the open mask, but discovered that its perfect fltting, after the lapse of some minutes, produced the laboured breathing which is seen with the bag inhaler. This does not occur with a loose gauze pad, though it forms sufficient protection from the undue escape of ether vapour, which is $2 \frac{1}{2}$ times hesvler than alr, and otherwise sinks away and is lost.

No open flame nor cautery must be brought within $3 \mathrm{ft}$. of the evaporating ether, which is inflammable.

One drawback to the use of the open method is the quantity of ether which passes into the atmosphere; but the amount used is much reduced after a little experience when with more faith less ether is found to be necessary. The difference of the method does not reduce the danger of the occurrence of acute bronchitis and pneumonia in patients with catarrh, chronic bronchitis, or emphysema, for whom ether is unsuitable, nor should it be continned If mucous râtes be zome andible during operations which, by reason of alter-pain, will pifepent the patient from coughing to clear out the bronchi, such as those upon the stomach and gall bladder.

Alcoholles, malarial subjects, and those with a familly history of insanity take chloroform better than ether, and will prove unsuitable patients for this method.

The open mask may be used after anaesthesia'has been induced with nitrous oxide and ether or the $C_{1} E_{2}$ mixture if preferred, but the simplicity, asepsis, and perfection of the method $a b$ initio leave little to be desired.

Messrs. Allen and Hanburys, of Wigmore Street, W., have rendered me assistance in preparing models for the open mask and bottle-stopper, for which I am greatly indebted to them.

2 Annals of Surgery, Part REFERENCES. $177, \mathrm{p} .460 .2$ Surgery, Gynaecology, and Obstetrics, vol. 1ii, No. 6, pp. 795 to 799 , December, 1906 .

\section{THE CONVEYANCE OF WHOOPING-COUGH}

FROM MAN TO ANIMALS BY DIRECT

\section{EXPERIMENT.}

By HUGH A. MACEWEN, M.B., CH.B., D.P.H.LOND. AND CAMB.

LATE RESIDENT ASSISTANT PHYSICIAN, BELVIDERE FEVER HOSPITAL, GLASGOW.

THE etiology of whooping-cough has been the object of much research, and many and varlous have been the theorles advanced on the subject. Of late years, however, the belief has been gaining ground that it is bacterial in origin.

Kopolic, by making cultures from the sputum on solldified hydrocele fluld, obtained pure growths of a small bacllius with rounded ends which he claimed to be the specific organism. Jochmonn and Krause discovered a small bacillus with rounded ends, very similar to the organism described by Eppendorf as the Bacillus pertussis. Vincenzi also clalms to have lsolated a bacillis which much resembles or is identical with that of Eppendorf. Mayennis, on the other hand, belleves that the disease is oue to a bacillus which finds a nidus on the Schneiderlan membrane of the nose. None of these observers have, however, been able to prove that the organisms isolated by them are the true cause of the disease, and thus its precise etiology still remaing obscure.

With the object of trying to throw light on certain aspects of this question, feeding experiments on animals were instituted, and it is for the purpose of calling attontion to one of these experiments, performed in Belvldere Hospital, Glaegow, that the present article is written.

A full-grown and In every way healthy cat was placed in confinement in a building far removed from the wards in which whooping-cough patlents were isolated. Sputum and vomited material were then collected from selected cases of typical whooping-cough without bronchopneumonia or other complications. These substances were mixed with milk and administered to the cat, which took to the new diet with a fair degree of relish. For seven days this emulsion of sputum, vomited material, and milk formed the animal's sole source of nutriment. At the end of that time it was put upon ordinary milk once more.

After about fourteen to seventeen days, it was noted that the cat was getting into a languid condition; it lay at the back of 1 tg cage, and took little note of what went on around it. It had little appetite; when milk was placed before it, it would lap a little without any of the zest which characterized its attitude towards food at the commencement of its confinement.

About a month after the beginning of the experiment it was noted that the animal had a choky congh, which was always followed by vomiting. Some time later it developed a spasmodic cough, accompanied by a wellmarked whoop, which even persons unacquainted with the nature of the experiment at once pronounced to be whooping-cough. When these spasms came on, the animal, rising and clinging to the bottom of the cage with Its claws, coughed and whooped in a manner which left no doubt as to the nature of its complaint.

The conclusions to be drawn from the above experiment would seem to be :

1. That.whooping-cough is beyond doubt an infectious disease.

2. That the speclfic virus is contained in the spatum or vomited material or both. 